\title{
Gut bacteria Akkermansia elicit a specific IgG response in CSF of patients with MS
}

Amélie Vallino, MD, Amélie Dos Santos, MS, Camille V. Mathé, Alexandra Garcia, MS, Jérémy Morille, MS, Emilie Dugast, PhD, Sita P. Shah, MS, Geneviève Héry-Arnaud, PharmD, PhD, Charles-Antoine Guilloux, MS, Patrick J. Gleeson, MD, Renato C. Monteiro, MD, PhD, Jean-Paul Soulillou, MD, Jean Harb, PhD, Edith Bigot-Corbel, PharmD, Laure Michel, MD, PhD, Sandrine Wiertlewski, MD, Arnaud B. Nicot, PhD, David-Axel Laplaud, MD, PhD, * and Laureline Berthelot, PhD*

Neurol Neuroimmunol Neuroinflamm 2020;7:e688. doi:10.1212/NXI.0000000000000688

MS is a chronic inflammatory disease of the CNS involving T cell and B cell responses. Recently, several studies have described modifications of specific bacterium abundances of gut microbiota in patients with remitting-relapsing MS compared with healthy individuals $\left(\right.$ see for review $\left.{ }^{1}\right)$. This was often associated with an increase in Akkermansia muciniphila bacteria. In experimental autoimmune encephalomyelitis, transfer of gut microbiota from patients with MS to mice induced proinflammatory responses and exacerbation of the disease, whereas microbiota from healthy volunteers (HVs) were less inflammatory. ${ }^{2,3}$ Because bacteria in the gut modulate immune responses, we assessed the antibody production against A muciniphila in patients with MS. In CSF, levels of anti-A muciniphila immunoglobulin G ( $\mathrm{IgG}$ ) were increased in patients with MS compared with controls, whereas no difference was found for levels of IgG against Escherichia coli, Fusobacterium necrophorum, Acinetobacter baumannii, Prevotella melaninogenica, and Bacteroides fragilis.

\section{Methods}

Patients with relapsing-remitting MS (RRMS, $\mathrm{n}=62$ ) were enrolled in the neurology department of CHU de Nantes. Sex and age-matched patients (HVs, $n=41)$, patients with noninflammatory neurologic disease (e.g., suffering from sudden headaches or idiopathic intracranial hypertension) (noninflammatory neurologic disease [NIND], $\mathrm{n}=23$ ), and patients with inflammatory neurologic disease (peripheral neuropathy, brain lymphoma) (inflammatory neurological disease [IND], $\mathrm{n}=10$ ) were used for comparison. Informed written consent was obtained from all the patients before any study-related procedure was performed. Patients had not received any disease-modifying drugs before the sampling.

IgG concentration was measured with an immunonephelometric assay performed using a Beckman Immage Analyzer (Beckman Coulter). To detect antibody against bacteria, ELISA tests were performed using serum and CSF samples. Briefly, bacteria lysates from A muciniphila, F necrophorum, $A$ baumannii, $P$ melaninogenica, and $E$ coli were coated on plates (Nunc) at $1 \mu \mathrm{g} / \mathrm{mL}$ of proteins in phosphate buffer saline (PBS). Bovine serum albumin (Sigma Aldrich) at $1 \%$ in PBS was used for blocking. Patient samples were incubated for 2 hours at $37^{\circ} \mathrm{C}$ in PBS (dilutions 1/ 100 for serum, $1 / 10$ for CSF) and $1 \%$ bovine serum albumin. Antihuman IgG antibodies coupled with horseradish peroxidase (Bethyl Laboratories) at $1 / 5,000,1$ hour at $37^{\circ} \mathrm{C}$, were used. The reaction with the substrate $\left(3,3^{\prime}, 5,5^{\prime}\right.$-Tetramethylbenzidine, BD Biosciences) was stopped with sulfuric acid (0.18M, Sigma Aldrich). Plates were read at $450 \mathrm{~nm}$ using a Spark $10 \mathrm{M}$ multimode

\author{
Correspondence \\ Dr. Berthelot \\ laureline.berthelot@inserm.fr
}


Figure Increased levels of Anti-Akkermansia IgG in RRMS CSF and correlation with the EDSS score

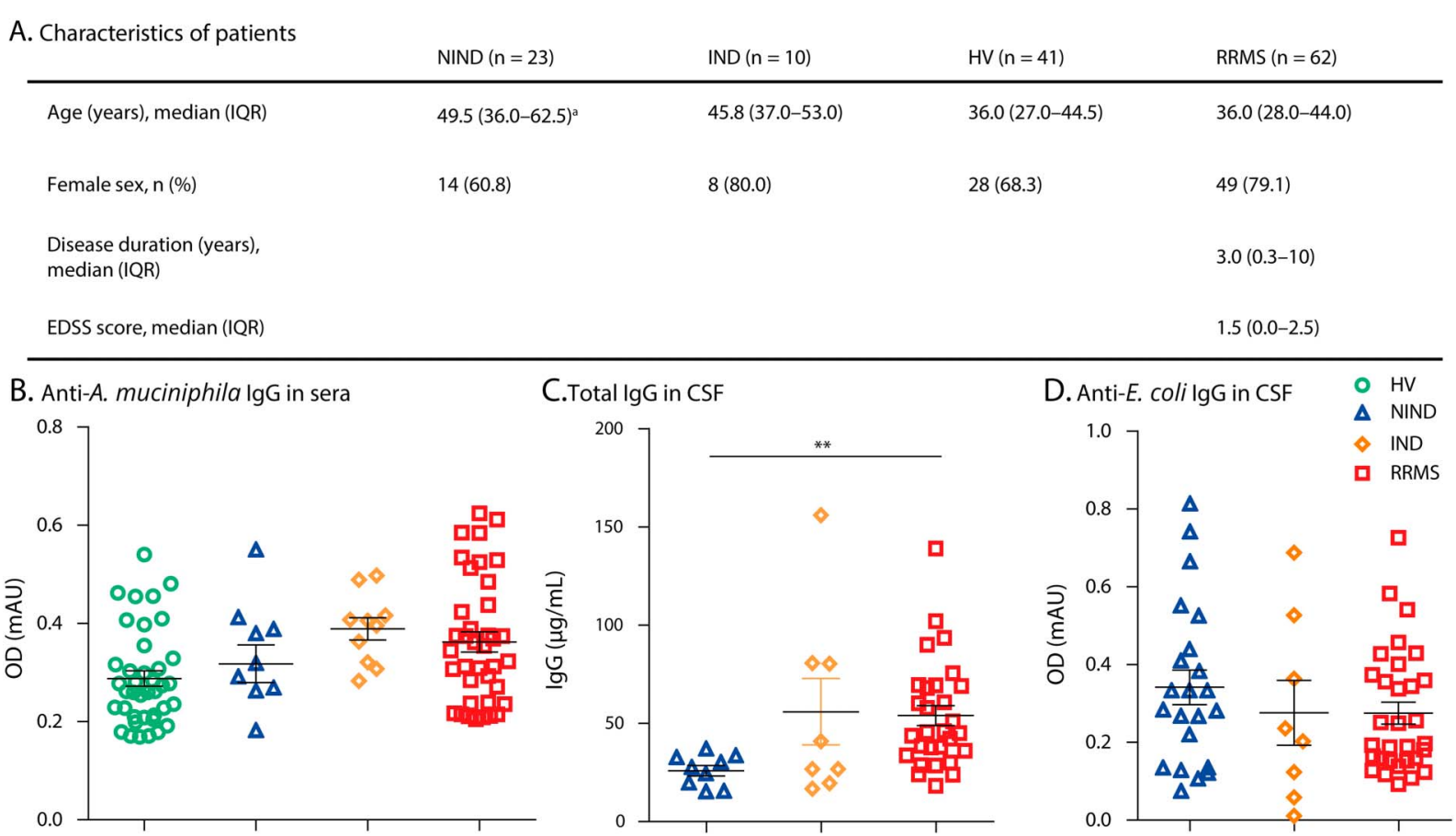

E. Anti-A. baumanii lgG in CSF

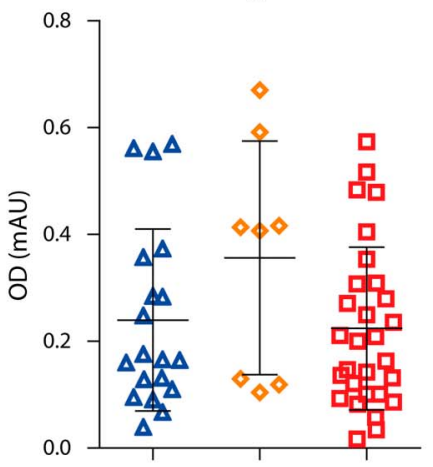

F. Anti-F. necrophirum IgG in CSF

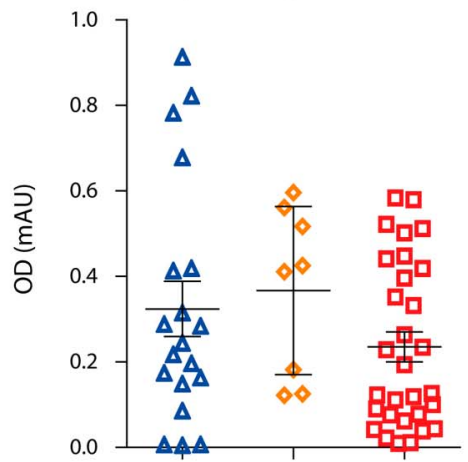

G. Anti-P. melaninogenica lgG in CSF

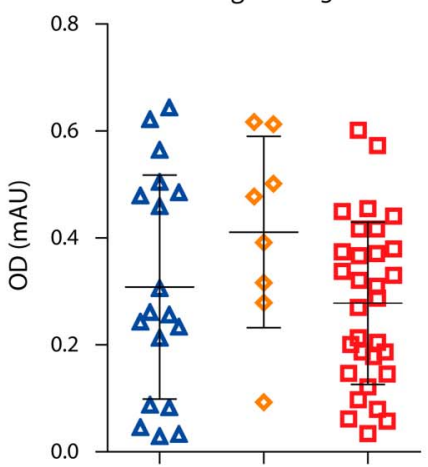

H. Anti-A. muciniphila IgG in CSF

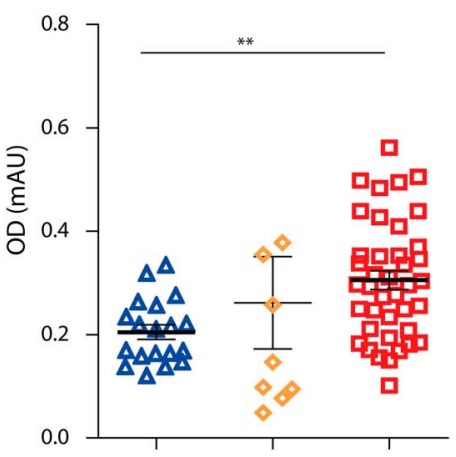

।

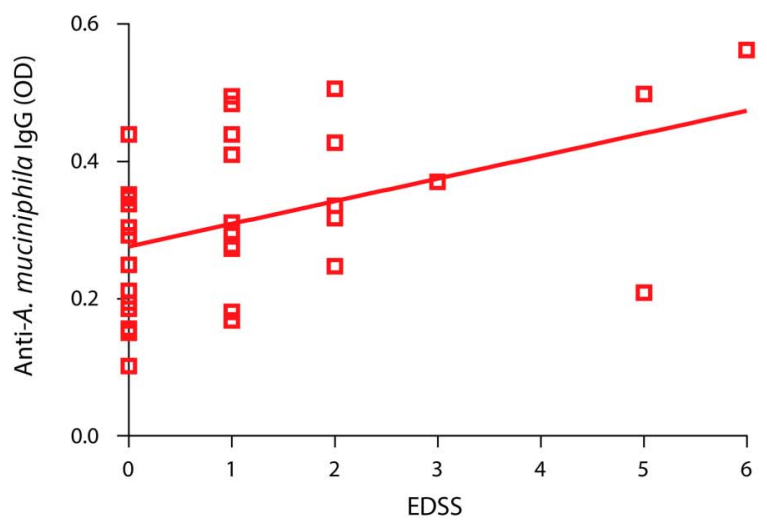

(A) Clinical characteristics of patients are listed in Table A. Patients with RRMS; patients with noninflammatory neurological disease of the CNS (NIND), patients with IND, and HVs; EDSS, median $\pm I Q R,{ }^{a} p<0.01$ NIND vs HV, and RRMS. (B) Levels of anti-Akkermansia muciniphila IgG in sera from patients with RRMS, NIND, IND, and HV. (C) Total IgG concentrations in CSF from patients with RRMS, NIND, and IND. (D) Levels of anti-Escherichia coli IgG in CSF from patients with RRMS, NIND, and IND. (E) Levels of anti-Acinetobacter baumannii IgG in CSF. (F) Levels of anti-Fusobacterium necrophorum IgG in CSF. (G) Levels of anti-Prevotella melaninogenica IgG in CSF. (H) Levels of anti-A muciniphila IgG in CSF. Mean \pm standard error. ** $p<0.01$. (I) Correlation between anti-A muciniphila IgG in CSF from patients with RRMS and EDSS score (Spearman's rank correlation rho $=0.36, p=0.027$ ). EDSS $=$ Expanded Disability Status Scale; HV = healthy volunteer; IND = inflammatory neurological disease; IQR = interquartile range; NIND = noninflammatory neurological disease; RRMS = relapsing-remitting MS 
microplate reader (Tecan). The mean values of optical density were compared using the Mann-Whitney test and analysis of variance with Dunn's multiple comparisons test for more than 2 groups. Aberrant values for biological variables were determined by a Dixon test and excluded.

\section{Results}

The levels of anti-A muciniphila IgG were measured by using ELISA in sera and appeared equivalent in patients with RRMS, NIND, IND, and HV (figure, B). The IgG levels of anti-E. coli, F. necrophorum, A baumannii, and $P$ melaninogenica were also similar in the tested groups (data not shown). As trations were increased in CSF from patients with RRMS compared with those of NIND $(p<0.01$, figure, C). There was no difference in the IgG levels against $E$ coli, $F$ necrogroups (figure, D-G). We were able to reveal an increased compared with those with NIND and IND $(p<0.005$, figure, $\mathrm{H})$. There was no correlation between the total $\operatorname{IgG}$ connot shown). Strikingly, the levels of anti-A muciniphila cor(rho $=0.36, p=0.027$, figure, I).

This is the first study to display that the levels of IgG against $A$ muciniphila are increased in CSF of patients with RRMS compared with control samples. Interestingly, anti-E Coli IgG levels in CSF were equivalent in patients with RRMS and controls, revealing a specific response against a particular bacterium. An increase in A muciniphila, Fusobacterium, and Acinetobacter bacteria and a decrease in Prevotella have been shown in the gut microbiota of patients with RRMS. However, we found that, although the CSF samples also exhibited an increase in anti- $A$ muciniphila IgG levels, no such modification was detected in the blood. This CSF-localized specific antibody signature suggests an intrathecal secretion of specific $B$ cells retained in the CNS compartment, which may have migrated from the gut. B cells were indeed found while draining cervical lymph nodes of patients with MS. ${ }^{4}$ These $\mathrm{B}$ cells were able to populate the CNS in this inflammatory context. Moreover, in a mouse model, plasma cells specific for commensal bacteria were diminished in the gut and circulate to the CNS, producing in situ immunoglobulins. ${ }^{5}$ The local role of anti-A muciniphila IgG in MS pathology remains yet to be elucidated. Antibodies could be also elicited or act through cross-reactivity/molecular mimicry to myelin components as was described recently for $\mathrm{T}$ cell responses to some microbiota-derived peptides. ${ }^{6}$ Thus, along with previous lines of evidence for gut microbiota modifications in MS, our present findings highlight a CNS-specific antibacterial antibody response in patients with RRMS. expected and previously described, the total IgG concenphorum, A baumannii, and $P$ melaninogenica in CSF from the 3 IgG reaction against $A$ muciniphila in patients with RRMS centration and levels of anti-A muciniphila IgG in CSF (data related with Expanded Disability Status Scale score in RRMS

\section{Discussion}

\section{Study funding}

This study was supported by the Région Pays de La Loire, ARSEP (Association for research on multiple sclerosis), and Antares foundations. This work has been carried out thanks to the support of the LabEx IGO project ( ${ }^{\circ}$ ANR-11-LABX0016-01) funded by the «Investissements d'Avenir » French Government program, managed by the French National Research Agency (ANR).

\section{Disclosure}

The authors report no disclosures relevant to the manuscript. Go to Neurology.org/NN for full disclosures.

\section{Publication history}

Received by Neurology: Neuroimmunology \& Neuroinflammation February 25, 2019. Accepted in final form January 17, 2020.

\begin{tabular}{|c|c|c|}
\hline Name & Location & Contribution \\
\hline $\begin{array}{l}\text { Amélie } \\
\text { Vallino, MD }\end{array}$ & $\begin{array}{l}\text { Center of Research in } \\
\text { Transplantation and } \\
\text { Immunology, Nantes, } \\
\text { France }\end{array}$ & $\begin{array}{l}\text { Major role in the } \\
\text { acquisition of data, } \\
\text { Interpreted the data }\end{array}$ \\
\hline $\begin{array}{l}\text { Amélie Dos } \\
\text { Santos, MS }\end{array}$ & $\begin{array}{l}\text { Center of Research in } \\
\text { Transplantation and } \\
\text { Immunology, Nantes, } \\
\text { France }\end{array}$ & $\begin{array}{l}\text { Major role in the } \\
\text { acquisition of data, } \\
\text { Interpreted the data }\end{array}$ \\
\hline $\begin{array}{l}\text { Camille V. } \\
\text { Mathé }\end{array}$ & $\begin{array}{l}\text { Center of Research in } \\
\text { Transplantation and } \\
\text { Immunology, Nantes, } \\
\text { France }\end{array}$ & $\begin{array}{l}\text { Major role in the } \\
\text { acquisition of data, } \\
\text { Interpreted the data }\end{array}$ \\
\hline $\begin{array}{l}\text { Alexandra } \\
\text { Garcia }\end{array}$ & $\begin{array}{l}\text { Center of Research in } \\
\text { Transplantation and } \\
\text { Immunology, Nantes, } \\
\text { France }\end{array}$ & $\begin{array}{l}\text { Major role in the } \\
\text { acquisition of data }\end{array}$ \\
\hline $\begin{array}{l}\text { Jeremy } \\
\text { Morille, MS }\end{array}$ & $\begin{array}{l}\text { Center of Research in } \\
\text { Transplantation and } \\
\text { Immunology, Nantes, } \\
\text { France }\end{array}$ & $\begin{array}{l}\text { Major role in the } \\
\text { acquisition of data }\end{array}$ \\
\hline $\begin{array}{l}\text { Emilie Dugast, } \\
\text { PhD }\end{array}$ & $\begin{array}{l}\text { Center of Research in } \\
\text { Transplantation and } \\
\text { Immunology, Nantes, } \\
\text { France }\end{array}$ & $\begin{array}{l}\text { Major role in the } \\
\text { acquisition of data }\end{array}$ \\
\hline
\end{tabular}

\begin{tabular}{lll}
\hline Sita P. Shah, & Center of Research in & $\begin{array}{l}\text { Revised the manuscript } \\
\text { for intellectual content }\end{array}$ \\
MS & $\begin{array}{l}\text { Transplantation and } \\
\text { Immunology, Nantes, }\end{array}$ & \\
& France &
\end{tabular}

\begin{tabular}{|c|c|c|}
\hline $\begin{array}{l}\text { Geneviève } \\
\text { Héry-Arnaud, } \\
\text { PharmD, PhD }\end{array}$ & CHU de Brest, France & $\begin{array}{l}\text { Major role in the } \\
\text { acquisition of data }\end{array}$ \\
\hline $\begin{array}{l}\text { Charles- } \\
\text { Antoine } \\
\text { Guiloux, MS }\end{array}$ & University of Brest & $\begin{array}{l}\text { Major role in the } \\
\text { acquisition of data }\end{array}$ \\
\hline $\begin{array}{l}\text { Patrick James } \\
\text { Gleeson, MD }\end{array}$ & $\begin{array}{l}\text { Center of Research on } \\
\text { Inflammation, Paris, } \\
\text { France }\end{array}$ & $\begin{array}{l}\text { Major role in the } \\
\text { acquisition of data }\end{array}$ \\
\hline $\begin{array}{l}\text { Renato Costa } \\
\text { Monteiro, } \\
\text { MD, PhD }\end{array}$ & $\begin{array}{l}\text { Center of Research on } \\
\text { Inflammation, Paris, } \\
\text { France }\end{array}$ & $\begin{array}{l}\text { Major role in the } \\
\text { acquisition of data; } \\
\text { revised the manuscript } \\
\text { for intellectual content }\end{array}$ \\
\hline
\end{tabular}


Appendix (continued)

\begin{tabular}{|c|c|c|}
\hline Name & Location & Contribution \\
\hline $\begin{array}{l}\text { Jean-Paul } \\
\text { Souillou, MD }\end{array}$ & $\begin{array}{l}\text { Center of Research in } \\
\text { Transplantation and } \\
\text { Immunology, Nantes, } \\
\text { France }\end{array}$ & $\begin{array}{l}\text { Revised the manuscript } \\
\text { for intellectual content }\end{array}$ \\
\hline $\begin{array}{l}\text { Jean Harb, } \\
\text { PhD }\end{array}$ & $\begin{array}{l}\text { Center of Research in } \\
\text { Transplantation and } \\
\text { Immunology, Nantes, } \\
\text { France }\end{array}$ & $\begin{array}{l}\text { Revised the manuscript } \\
\text { for intellectual content }\end{array}$ \\
\hline $\begin{array}{l}\text { Edith Bigot- } \\
\text { Corbel, } \\
\text { PharmD, PhD }\end{array}$ & CHU de Nantes, France & $\begin{array}{l}\text { Major role in the } \\
\text { acquisition of data }\end{array}$ \\
\hline $\begin{array}{l}\text { Laure Michel, } \\
\text { MD, PhD }\end{array}$ & $\begin{array}{l}\text { Center of Research in } \\
\text { Transplantation and } \\
\text { Immunology, Nantes, } \\
\text { France }\end{array}$ & $\begin{array}{l}\text { Major role in the } \\
\text { acquisition of data }\end{array}$ \\
\hline $\begin{array}{l}\text { Sandrine } \\
\text { Wiertlewski, } \\
\text { MD }\end{array}$ & $\begin{array}{l}\text { Center of Research in } \\
\text { Transplantation and } \\
\text { Immunology, Nantes, } \\
\text { France }\end{array}$ & $\begin{array}{l}\text { Major role in the } \\
\text { acquisition of data }\end{array}$ \\
\hline $\begin{array}{l}\text { Arnaud B. } \\
\text { Nicot, PhD }\end{array}$ & $\begin{array}{l}\text { Center of Research in } \\
\text { Transplantation and } \\
\text { Immunology, Nantes, } \\
\text { France }\end{array}$ & $\begin{array}{l}\text { Interpreted the data; } \\
\text { revised the manuscript } \\
\text { for intellectual content }\end{array}$ \\
\hline
\end{tabular}

Appendix (continued)

\begin{tabular}{lll}
\hline Name & Location & Contribution \\
\hline $\begin{array}{l}\text { David-Axel } \\
\text { Laplaud, MD, } \\
\text { PhD }\end{array}$ & $\begin{array}{l}\text { Center of Research in } \\
\text { Transplantation and } \\
\text { Immunology, Nantes, } \\
\text { France }\end{array}$ & $\begin{array}{l}\text { Interpreted the data; } \\
\text { revised the manuscript } \\
\text { for intellectual content }\end{array}$ \\
\hline $\begin{array}{l}\text { Laureline } \\
\text { Berthelot, } \\
\text { PhD }\end{array}$ & $\begin{array}{l}\text { Center of Research in } \\
\text { Transplantation and } \\
\text { Immunology, Nantes, }\end{array}$ & $\begin{array}{l}\text { Design and } \\
\text { conceptualized study; } \\
\text { analyzed the data; } \\
\text { drafted the manuscript } \\
\text { for intellectual content }\end{array}$ \\
& France & \\
\hline
\end{tabular}

\section{References}

1. Freedman SN, Shahi SK, Mangalam AK. The "gut feeling": breaking down the role of gut microbiome in multiple sclerosis. Neurotherapeutics 2018;15:109-125.

2. Berer K, Gerdes LA, Cekanaviciute E, et al. Gut microbiota from multiple sclerosis patients enables spontaneous autoimmune encephalomyelitis in mice. Proc Natl Acad Sci U S A 2017;114:10719-10724.

3. Cekanaviciute E, Yoo BB, Runia TF, et al. Gut bacteria from multiple sclerosis patients modulate human T cells and exacerbate symptoms in mouse models. Proc Natl Acad Sci U S A 2017;114:10713-10718.

4. Stern JN, Yaari G, Vander Heiden JA, et al. B cells populating the multiple sclerosis brain mature in the draining cervical lymph nodes. Sci Transl Med 2014;6:1-10.

5. Rojas OL, Probstel AK, Porfilio EA, et al. Recirculating intestinal IgA-producing cells regulate neuroinflammation via IL-10. Cell 2019;176:610-624.

6. Planas R, Santos R, Tomas-Ojer P, et al. GDP-l-fucose synthase is a CD4(+) T cellspecific autoantigen in DRB3 ${ }^{*} 02: 02$ patients with multiple sclerosis. Sci Transl Med $2018 ; 10: 1-15$ 


\section{Neurology \\ Neuroimmunology \& Neuroinflammation}

Gut bacteria Akkermansia elicit a specific IgG response in CSF of patients with MS

Amélie Vallino, Amélie Dos Santos, Camille V. Mathé, et al.

Neurol Neuroimmunol Neuroinflamm 2020;7;

DOI 10.1212/NXI.0000000000000688

This information is current as of March 2, 2020

\section{Updated Information \& Services}

References

Subspecialty Collections

Permissions \& Licensing

Reprints including high resolution figures, can be found at:

http://nn.neurology.org/content/7/3/e688.full.html

This article cites 6 articles, 2 of which you can access for free at: http://nn.neurology.org/content/7/3/e688.full.html\#\#ref-list-1

This article, along with others on similar topics, appears in the following collection(s):

Autoimmune diseases

http://nn.neurology.org//cgi/collection/autoimmune_diseases

Cerebrospinal Fluid

http://nn.neurology.org//cgi/collection/cerebrospinal_fluid

Multiple sclerosis

http://nn.neurology.org//cgi/collection/multiple_sclerosis

Information about reproducing this article in parts (figures,tables) or in its entirety can be found online at:

http://nn.neurology.org/misc/about.xhtml\#permissions

Information about ordering reprints can be found online:

http://nn.neurology.org/misc/addir.xhtml\#reprintsus

Neurol Neuroimmunol Neuroinflamm is an official journal of the American Academy of Neurology.

Published since April 2014, it is an open-access, online-only, continuous publication journal. Copyright

Copyright $\odot 2020$ The Author(s). Published by Wolters Kluwer Health, Inc. on behalf of the American

Academy of Neurology.. All rights reserved. Online ISSN: 2332-7812.

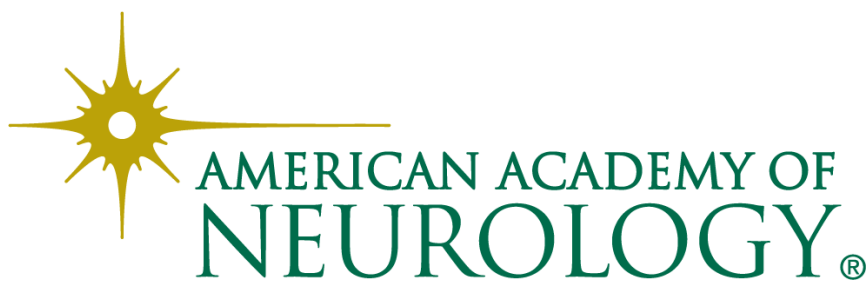

